\title{
Um projecto novecentista para alfabetização do exército português
}

\author{
A XIX century's project to improve literacy in the \\ Portuguese army
}

\section{Un projet du siècle XIX pour l'alphabétisation de l'armée portugaise}

José Carlos de Oliveira CASULO

\section{RESUMO}

Neste artigo investiga-se um projecto de alfabetização do exército português naquela que foi a sua concepção legal (1815/1816) e quanto aos resultados obtidos ao quinto ano (1820) do seu desenvolvimento.

Começa-se por analisar os objectivos do referido projecto, os assuntos, compêndios e métodos de ensino, bem como o calendário e horário lectivos e as recomendações sobre o que deveria ser a relação pedagógica. Apresentamse, depois, os resultados obtidos e as idades dos alunos militares, terminando-se com uma referência às categorias, selecção e formação dos professores.

Anexa-se uma transcrição, actualizada e revista, de um documento manuscrito de 1822 , de que foi autor o responsável máximo do exército sobre este processo de alfabetização, Capitão João Crisóstomo do Couto e Melo.

Palavras- chave: Portugal - alfabetização - exército - século XIX

\begin{abstract}
This article investigates a literacy improvement's project of the Portuguese army in its legal conception (1815/1816) and the results obtained at the fifth year (1820) of its development.

It begins by examining the aims, the issues, compendiums and teaching methods of that project, as well as the school calendar and schedule and the recommendations on what should be the pedagogical relationship. After that, achieved results and the age of military students are presented, being made, then, a reference to the categories, selection and training of teachers.

Attached is an updated and revised transcription of a handwritten document from 1822, whose author was the army's most responsible officer on this process, Captain João Crisóstomo do Couto e Melo.
\end{abstract}

Index terms: Portugal - literacy - army - XIX century. 


\section{RESUME}

Cet article étudie un projet d'alphabétisation de l'armée portugaise dans ce qui était le concept juridique (1815/1816) et les résultats obtenus à partir de la cinquième année (1820) de son développement.

Il commence par l'examen des objectifs de ce projet, les enjeux, les recueils et les méthodes pédagogiques et aussi le calendrier scolaire et les recommandations sur ce que devrait être l'éducation. Les résultats sont préséntés, ainsi que les âges des élèves militaires, se terminant par une référence aux catégories, la sélection et la formation des enseignants.

Elle est accompagnée d'une transcription mise à jour et révisée d'un document manuscrit de 1822, dont l'auteur était le Capitaine Jean Chrysostome do Couto e Melo, le responsable majeur de l'armée de ce processus d'alphabétisation.

Mots-clés: Portugal, alphabétisation, armée, XIXe siècle.

\section{Nota introdutória}

Apresentando-se sob várias formas, a educação de adultos esteve presente na História de Portugal desde os seus primórdios, a provar, aliás, que "ao longo dos séculos (...) houve uma paideia portuguesa" (Ruas, pp. 269). Promoveu-a a Igreja, promoveu-a a sociedade e promoveu-a a governação, esta última por vezes delegando em terceiros a responsabilidade pela sua execução prática, como aconteceu com a tarefa de alfabetização das suas praças (mas não só) atribuída ao exército no início de século de novecentos.

$\mathrm{Na}$ presente comunicação propomo-nos, precisamente, dar conta da concepção e resultados do primeiro lustro desse projecto de alfabetização de adultos militares portugueses sobre o qual se começou a legislar em 1815. Sem prejuízo do recurso pontual documentação secundária, serão nossas fontes principais os normativos legais pertinentes, publicados naquele ano e no que lhe sucedeu, bem como a parte do relatório de 1821 referente aos resultados do trabalho efectuado entre os anos de 1815 a 1820, relatório este assinado pelo Capitão de Engenharia João Crisóstomo do Couto e Melo, Director das Escolas Militares de Primeiras Letras. 
Começaremos por apresentar a concepção pedagógica deste projecto, já nos objectivos que o norteavam, já nas instruções delineadas para a prática quotidiana. Passaremos, depois, a delimitar a idade e os universos, potencial e efectivo, dos alfabetizandos militares, bem como os resultados globais obtidos até 1820. Por fim, apresentaremos os aspectos relacionados com a formação dos docentes envolvidos.

Em anexo, transcrevemos, revendo a pontuação e actualizando a ortografia, um manuscrito de 9 de Janeiro de 1822 do Director Geral das Escolas, que, pese embora não se tratar de um documento legal, possui valor documental histórico - e só por isto mesmo valeria a pena apresentá-lo - e nos permite perceber da vontade deste altíssimo responsável em que o método de ensino mútuo ${ }^{1}$ fosse integralmente assumido nas escolas regimentais.

\section{As escolas regimentais de primeiras letras: criação, objectivos e vertente pedagógica}

Foi em 10 de Outubro de 1815 que, por portaria da mesma data, D. João VI criou "uma Aula de ler, escrever, e contar, em cada Corpo de Infantaria, Caçadores, Cavalaria, e Artilharia do (...) Exército, e na Guarda Real de Polícia de Lisboa" ${ }^{2}$ (Portugal, 1815, p. 1).

De acordo com este mesmo documento, à fundação destas aulas presidiam quatro objectivos. O primeiro era o de responder ao desejo particular que o Soberano tinha de "promover nos Corpos de Linha do seu Exército o conhecimento da leitura, e escrita Portuguesa" (ibidem). O segundo era conferir uma habilitação literária mínima às praças que aspirassem ser promovidas a oficiais inferiores, isto é, a sargentos. O terceiro consistia em, de um modo geral, fornecer as ferramentas intelectuais básicas a todos os militares

\footnotetext{
${ }^{1}$ Se bem que as Instruções... de 1816 não o mencionem, o método de ensino nelas pressuposto, mas só explicitamente indicado para as três primeiras classes de leitura, assentava no método de ensino mútuo (sistema de Madras ou método de Lancaster), iniciado por Andrew Bell (1753-1832) em Madras, na Índia britânica, e desenvolvido em Inglaterra por Joseph Lancaster (1778-1838).

${ }^{2}$ Nas citações actualiza-se a grafia do texto original.
} 
que, sem outro interesse, pretendessem adquiri-las. O último objectivo era similar ao terceiro, do qual se diferenciava apenas por se aplicar a crianças, fossem elas os filhos dos militares do quartel em que estivesse instalada a escola, fossem os "filhos dos habitantes das Terras, ou Bairros em que os mesmos Corpos tiverem os seus Quartéis" (ib.). Vemos, pois, que esta alfabetização dos militares do exército, que enquanto tal era alfabetização de adultos, viria a servir, também, para crianças, dimensão esta de que, neste estudo, não nos ocuparemos.

A concepção normativa destas escolas militares ficou plasmada nas Instruções para os Professores das Escolas de Primeiras Letras dos Corpos de Linha do Exército, datadas de 29 de Outubro de 1816, as quais se iniciavam determinando que, para que se constituíssem as escolas, o professor, logo que tivesse os alunos matriculados, averiguasse o seu nível de literacia e, em função da avaliação feita, os distribuísse por seis classes de leitura e três de escrita.

Cada uma das classes de leitura tomaria o nome da matéria nela tratada, pelo que teríamos, numa ordem ascendente, as classes de Alfabeto, de Silabário, de Vocabulário, de Leitura de Frases e Períodos, de Etimologia e Sintaxe e, por fim, de Ortografia e Pontuação. Todo o ensino da leitura se faria com base nos manuais que tinham servido para a formação dos próprios docentes, a saber, “o Novo Método de Ensinar, e Aprender a Pronunciação e Leitura da Língua Portuguesa (...) e o novo Epítome da Gramática portuguesa" (Portugal, 1816b, p. 4). Para a aprendizagem, as três primeiras classes eram divididas "em Decúrias formadas de quatro Alunos cada uma; e nomeando para Decuriões delas os Alunos das Classes quarta, quinta, e sexta: durante esta hora deverá o Ajudante dirigir o ensino da Leitura" (ibidem, p. 2), enquanto que os alunos das três últimas classes de leitura aprendiam com o Mestre.

As três classes de escrita seriam caracterizadas, cada uma delas, pelo material sobre o qual os estudantes escreveriam, “devendo formar a primeira 
Classe os Alumnos que escreverem sobre areia; a segunda os que escreverem sobre a pedra ardósia; e a terceira os que principiarem a escrever sobre papel" (ib., p. 1). Cada uma destas classes subdividir-se-ia nos seis seguintes níveis, correspondentes à forma de escrita nele exercitada: $1^{\circ}$ ) letras minúsculas, $2^{\circ}$ ) letras maiúsculas, $3^{\circ}$ ) alfabetos minúsculos, $4^{\circ}$ ) alfabetos maiúsculos, $5^{\circ}$ ) escrito corrente em letra bastarda, $6^{\circ}$ ) escrito corrente em letra cursiva. Tal como na leitura, o compêndio a utilizar seria o que tinha servido na Escola Geral onde os docentes se tinham formado, de seu título "Nova Arte de Ensinar, e Aprender a Escrever" (ib., p. 4). O ensino da escrita era da responsabilidade do Mestre no concernente aos alunos que frequentassem as três primeiras classes de leitura, sendo os restantes instruídos pelo Ajudante.

Quanto ao cálculo, os alunos das três primeiras classes de leitura aprenderiam Princípios Gerais de Numeração, cabendo aos das três últimas classes o estudo de Cálculo Aritmético, observando esta ordem: “Operações Fundamentais de Composição e Decomposição dos Números inteiros (...) dos Números Quebrados (...) [e] dos Números Complexos; (...) Razões, Proporções e sua aplicação à Regra de três termos" (ib.). Recorrer-se-ia, neste ensino, aos "Elementos Compostos para uso dos Alunos do Real Colégio Militar da Luz" (ib.). No cálculo, o Ajudante responsabilizava-se pelos escolares das três primeiras classes de leitura e o Mestre pelos demais.

Se bem que as Instruções... de 1816 apenas exemplifiquem o método de ensino no caso da aprendizagem da leitura e só nas três primeiras classes, não resulta do texto que se pretendesse que em todos os demais casos -últimas três classes de leitura e classes de escrita e de cálculo- não se deveria empregar método semelhante. Pelo contrário: estipulando o artigo $21^{\circ}$ que "Na última Aula da semana deverá o Ajudante da Escola entregar ao Professor as Escalas do Progresso dos Decuriados (C) dessa mesma semana para serem reformadas as Decúrias, que deverá haver na semana próxima futura” (ib., pp. 5-6), logo no artigo imediato se ordena que "Igualmente serão reformadas as Classes, e 
Ordens de Escritura no ultimo dia de Aula por semana, e o mesmo se deverá fazer das Classes de Aritmética" (ib., p. 6) . $^{3}$

Com excepção das tardes de Sábado, as escolas regimentais funcionariam em todos os dias úteis do ano, cinco horas e meia entre Outubro e Março (das $7 \mathrm{~h}$ às $9 \mathrm{~h}$ e das $13 \mathrm{~h}$ às $16,30 \mathrm{~h}$ ) e seis horas entre Abril e Setembro (das $10 \mathrm{~h}$ às $13 \mathrm{~h}$ e das $15 \mathrm{~h}$ às $18 \mathrm{~h}$ ). Não havia férias de Verão, como se vê, sendo as aulas, contudo, interrompidas por altura do Carnaval, da Páscoa e do Natal, bem como nos "dias Aniversários de Suas Majestades" (ib., p. 6) . Para exames, de acordo com o manuscrito de 9 de Janeiro de 1822 do Director Geral das Escolas, adiante transcrito, reservar-se-iam, os três primeiros dias de aulas dos meses de Junho e de Dezembro:

Os discípulos que pretenderem fazer seus exames nas diferentes classes de instrução, pode o mestre admiti-los em três dias para isso mesmo destinados, nos primeiros dias de aula dos meses de Junho e Dezembro de cada ano (Melo, 1822, p. VI verso).

Sobre a relação pedagógica, exigiam as Instruções ..., nos artigos $42^{\circ} \mathrm{e}$ $43^{\circ}$, que os discentes, face aos professores, se mostrassem dóceis, respeitosos e gratos pela dádiva do ensino que estes lhes faziam, dádiva esta que, por em última análise ser oriunda da vontade do Soberano que levara à criação das escolas regimentais, deveria ser extensível, segundo o artigo $44^{\circ}$, à pessoa Real, "o que o Mestre não deixará de lhe[s] fazer conhecer, e inculcar em toda a ocasião oportuna" ((Portugal, 1816b, p. 10). Aos professores pedia-se-lhes que fossem capazes de levar os alunos a reconhecerem-lhes autoridade, não pela imposição rude de si mesmos, mas conseguindo-o, sim, com elevação. Pelo seu evidente e profundo significado, não resistimos a citar, a este propósito, os $\operatorname{artigos} 30^{\circ}$ e $31^{\circ}$ :

\footnotetext{
${ }^{3}$ Remetemos para os pontos $3^{\circ}$ a $19^{\circ}$ das instruções expostas no manuscrito de 9 de Janeiro de 1822 , do Director Geral das Escolas, que se transcreve em anexo a este artigo, de cuja leitura resulta que neste texto se previa explicitamente o uso do método do ensino mútuo em todas as classes de todas as matérias, fornecendo-se, com grande pormenor orientações sobre todo este processo
} 
$30^{\circ}$ Todas as Pessoas encarregadas da Educação, devem ter autoridade sobre as pessoas educadas: mas esta autoridade não é mais do que hum certo ar, e uma certa ascendência capaz de conciliar aos Mestres o respeito necessário, para serem obedecidos dos seus Discípulos; por tanto deverá ser proscrito das Escolas o emprego de ameaças e palavras injuriosas, que são sempre huma prova de se haver tido baixa educação, e de se possuir espírito mui grosseiro.

$31^{\circ}$ Hum carácter de espírito igual, moderado e firme, que só tem por guia a razão, e que não obra jamais por capricho, nem arrebatamento, é o que verdadeiramente dá ao Mestre o respeito sólido, e autoridade legitima sobre os seus Discípulos.” (ib., p. 7).

Uma derradeira palavra se deixe sobre o que era disposto quanto à educação cívica e à educação religiosa. A primeira, deviam os professores ministrá-la sobretudo dando exemplo "de urbanidade, polidez e franqueza do homem civilizado: devendo ter sempre em vista que todas as suas maneiras, por mais indiferentes que sejam, serão vistas, pesquisadas, e mesmo analisadas pelos seus Discípulos" (ib., pp. 6-7). A segunda cabia ao capelão, que, para além de iniciar as suas aulas com determinadas orações e de, na sua docência, seguir o livro Doutrina Christã mandado imprimir para uso das Escolas Militares, deveria ter um especial cuidado em fazer com que os alunos descobrissem que todo o ensino que lhes era ministrado só tinha sentido na medida em que os levasse a "saber, e praticar tudo o que convém ao homem de bem, ao bom Vassalo, e ao bom Cristão" (ib., p. 6).

\section{Universo (potencial e efectivo) e idade dos alunos militares}

Como se viu logo no início do ponto anterior, as escolas regimentais deviam ser criadas à razão de uma por cada corpo de linha do exército, e exclusivamente nos corpos de linha do exército, os quais se discriminavam como sendo cinquenta e três: "24 Regimentos de Infantaria, (...) 12 Batalhões de Caçadores, (...) 12 Regimentos de Cavalaria, (...) 4 Regimentos de Artilharia e (...) Corpo da Guarda Real de polícia de Lisboa” (Portugal, 1815, 
p. 2). Ora, os corpos, isto é, os regimentos ou batalhões de linha, constituíam o exército pago e profissionalizado, a tropa de primeira linha, como também era denominada para se diferenciar da tropa de segunda linha, composta pelas unidades militares de Ordenanças e Milícias. Por consequência, os membros destas últimas eram excluídas do universo de potenciais frequentadores das aulas militares de ler, escrever e contar criadas pela portaria de 10 de Outubro de 1815 .

Tenhamos em conta, contudo, que, entre esta portaria e o início efectivo das aulas mediou, pelo menos, o tempo que foi necessário despender na selecção e formação dos professores necessários à concretização da tarefa em causa, assunto este sobre o qual a própria portaria de 1815 estipulou algumas normas, como adiante se verá.

Tenhamos em conta, ainda, que, quatro meses volvidos, em 16 de Fevereiro de 1816, um alvará desta data aprovou o regulamento que reorganizava o exército português, alvará este em que, ao número de regimentos e batalhões já existentes e elencados na portaria de 10 de Outubro de 1815, foram acrescentadas novas unidades, a saber, um batalhão de Engenharia e outro agrupamento formado por quatro companhias de artilheiros condutores. Na sua totalidade, previa-se que, a partir deste regulamento de 1816, a primeira linha do exército português passasse a ser assim composta:

24 Regimentos de Infantaria, 37.248 homens - 12 Batalhões de Caçadores, 8.316 homens - 12 Regimentos de Cavalaria, 7.140 homens e 6.372 cavalos - 4 Regimentos de Artilharia, 3.568 homens - 1 Batalhão de Artífices Engenheiros, 681 homens - 4 Companhias de Artilheiros Condutores, 276 homens e 400 cavalos. Soma geral, 57,229 homens e 6.772 cavalos (Portugal, $1816^{\text {a }}$, p. 7).

As escolas regimentais, contudo, destinavam-se, no universo militar, às praças que pretendessem vir a "ocupar os diversos Postos Militares na Classe de Oficiais Inferiores" (Portugal, 1815,. p. 1), da classe de sargentos, pois, se bem que, como já atrás se frisou, não estivessem fechadas a quaisquer outros 
militares que as quisessem frequentar. Cingindo-nos aqui ao número dos possíveis futuros sargentos e não incluindo nele os soldados com funções auxiliares $^{4}$, mas tão só os cabos, anspeçadas e soldados operacionais, teríamos, de acordo com o que é possível extrair do artigo VI do regulamento de 16 de Fevereiro de 1816, um universo potencial de mais de cinquenta mil alunos, sem descontar, porque se trata de uma tarefa na prática inexequível, os que, analfabetos ou alfabetizados, não pretendessem cursar a escola do seu regimento ou batalhão, coisa a que, aliás, não eram obrigados.

Contudo, o universo efectivo dos alunos militares que passaram por estas escolas até 1820 foi notoriamente menor. Com efeito, sabemos pelo relatório de João Crisóstomo de Couto e Melo que, naquele ano, "em todas as 56 Escolas, incluindo a Escola Geral (...) matricularam-se 351 militares” (Melo, 1821, p. IX), dos quais só quarenta e dois conseguiram obter aprovação. Informa-nos a mesma fonte que, desde o início do funcionamento das escolas, era de seiscentos e vinte e um o número de militares não aprovados e de duzentos e catorze o número de praças promovidas a oficiais inferiores (sargentos). Em suma: até final do ano de 1820, temos a certeza de terem frequentado as escolas regimentais oitocentos e trinta e cinco militares, tendo em conta o número de reprovados e o de promovidos a sargentos que o relatório do Capitão João Crisóstomo Melo fornece. Haveria que acrescentar a estes, naturalmente, os eventualmente aprovados mas não promovidos a sargentos, sobre os quais nada nos diz o referido relatório.

Passando a averiguar a idade dos soldados escolares, podemos aceitar, a partir dos dados a seguir explicitados, que ela oscilaria entre os dezoito e os trinta anos de idade, podendo mesmo exceder este último limite. Realmente, em 1809, o alvará de 15 de Dezembro, invocando "a injusta agressão de um inimigo" (Portugal, 1809, p. 1), ou seja, a realidade das investidas napoleónicas sobre Portugal, mandava recrutar, sem prejuízo das excepções que eram

\footnotetext{
${ }^{4}$ Corneteiros, tambores, pífaros, trombetas, ferradores, seladores, picadores, alveitares, espingardeiros e coronheiros.

${ }^{5}$ Exactamente 51.704, assim distribuídos: 33.600 de Infantaria, 7.200 de Caçadores, 6.144 de Cavalaria, 3.200 de Artilharia, 960 das companhias de artilheiros condutores e 600 de Engenharia.
} 
indicadas, "Todos os homens solteiros de idade de dezoito a trinta e cinco anos" (ibidem, p. 2). Mas, no ano seguinte, continuando o país sob a ameaça francesa, novas regras levantaram para os quarenta anos a idade limite de recrutamento: "Ficam sujeitos ao Recrutamento todos os Homens solteiros de idade de dezoito até quarenta anos" (Portugal, 1810, p. 1)). Três anos volvidos, em 1813, já dissipado o cenário bélico de 1809 e 1810, uma portaria de 28 de Setembro diminui o limite superior de idade para trinta anos: "Ficam por tanto sujeitos ao Recrutamento de Tropa de Linha todos os indivíduos nacionais e naturalizados, compreendidos nas idades de dezoito a trinta anos" (Portugal, 1813, p. 6), directiva esta que o regulamento reorganizador do exército de 1816 sancionava ao estipular que se procedesse de modo a "quanto for possível, ter o Exército sempre composto de homens, que não tenham menos de 18 anos de idade, nem mais de 30" (Portugal, 1816, p. 15).

A expressão quanto for possível, aliada ao facto de as disposições anteriores sobre recrutamento estipularem a arregimentação de homens até aos trinta e cinco e mesmo quarenta anos, que poderiam, entretanto, ter permanecido nas fileiras, fazem-nos não excluir a possibilidade de se terem matriculado alguns alunos com idade superior a trinta anos.

\section{Categorias, selecção e formação do pessoal docente}

As instruções anexas à portaria de 10 de Outubro de 1815 elucidam-nos sobre as categorias dos professores e respectivas selecção e formação. As escolas contariam com um "um Mestre, um Ajudante do Mestre, e na falta do Ajudante (...) um Aspirante" (Portugal, 1815, p. 2), os quais, se já o não fossem, receberiam as patentes de, respectivamente, $1^{\circ}$ sargento agregado, $2^{\circ}$ sargento agregado e cabo agregado.

Mestres, Ajudantes e Aspirantes seriam seleccionados por concurso, de entre o universo dos sargentos e praças do regimento ou batalhão que acolhesse a escola. Os critérios a empregar nesta selecção eram assim fixados:

Os Indivíduos concorrentes devem saber suficientemente: $1^{\circ}$ ler letra impressa, e manuscrita: $2^{\circ}$ escrever letra bastarda, 
bastardinha, e cursiva: $3^{\circ}$ fazer as quatro operações fundamentais de Aritmética em números inteiros, e quebrados; devendo unir a estes conhecimentos uma boa conduta moral, e civil (ibidem).

Ficando deserto o concurso, recorrer-se-ia, pela seguinte ordem, a "concorrentes de outros [regimentos e batalhões], e bem assim Milicianos, e mesmo Paisanos" (ib.).

Uma vez seleccionados e antes de iniciarem funções, tinham os docentes que seguir, em Lisboa, o curso da Escola Geral de Belém, a estabelecer e manter enquanto fosse justificável a sua existência, isto é, até que tivesse "aprontado os Alunos necessários para preencherem os referidos Empregos [de Mestre, Ajudante e Aspirante] em todos os Corpos" (ib.), curso este que visava garantir a uniformidade do ensino nas diferentes escolas regimentais. Era neste sentido que ao seu Director, sempre um oficial de patente não inferior a capitão, incumbia zelar para que os futuros professores aprendessem "pelo mesmo método que prescrevem as instruções que hão-de servir de Regulamento às Escolas particulares dos Corpos" (ib., p. 3).

\section{Nota final}

Se bem que na França de finais do ancien regime já se tivesse evidenciado a preocupação coma alfabetização de adultos, a orientação desta preocupação para os adultos militares, na mesma França, só viria a verificar-se após a lei de 1827 que tornou o recrutamento obrigatório. Se atendermos a que falar da França, nesta época, é sempre falar do país que iluminava a cultura europeia, e em grau superlativo a vertente latina desta cultura, então podemos dizer que as escolas regimentais portuguesas foram estabelecimentos pioneiros, de um período também pioneiro na educação de adultos.

Foram-no, até, com aquele toque de elevação e desprendimento que forma a substância do agir cultural, na medida em que um dos objectivos que presidiu à sua criação era permitir a sua frequência também por quem, sendo militar, nelas se inscrevesse movido apenas pela avidez do saber, mesmo que 
num grau elementar. Mas a letra das disposições legais obriga a que, ao lado deste alto ideal, coloquemos o facto de elas, para além de também poderem acolher crianças, se destinarem a responder ao desiderato, bem assente na vida real, de conferir uma habilitação às praças que queriam ascender a sargentos.

Por outro lado, a discrepância entre os potenciais e os efectivos alunos militares mostra, como seria de esperar, que muito escassa era a quantidade dos soldados desejosos de se cultivarem sem qualquer outro interesse, o que nos leva a concluir que, no lapso de tempo aqui estudado, o mérito do pioneirismo destas escolas foi contrabalançado pelos fracos resultados obtidos ao nível dos adultos que as frequentaram.

Também não se pode deixar de notar que aos professores, sob o ponto de vista dos seus conhecimentos, pouco ou nada mais lhes era exigido que soubessem para além daquilo que iam ensinar, o que significa que, neste aspecto, estariam ao nível dos seus alunos que viessem a ser aprovados. Exigiase-lhes, isso sim, que fossem capazes de reproduzir nas suas escolas, sem qualquer margem para alterações, o ensino que tinham recebido na Escola Geral de Belém, isto é, que praticassem com um público subalterno exactamente o mesmo que os seus superiores tinham praticado com eles, que fossem como que o elo intermédio de uma espécie de cadeia de comando escolar. Autênticos sargentos, portanto.

Assim, nas escolas regimentais portuguesas o trabalho de alfabetização reproduzia a estrutura hierárquica de um corpo de tropas. O peso desta omnipresença dos modi vivendi et faciendi castrenses notava-se, ainda, na uniformização (o mesmo método e o mesmo livro para todos, por exemplo) e no controle centralizado que imperavam e que demonstravam que este projecto das escolas militares de primeiras letras não tinha sido delineado ao acaso, mas antes tinha sido pensado maduramente, tendo-se mesmo inspirado em referenciais pedagógicos com os quais as mais altas patentes de então estavam familiarizadas. Comandado que era o exército português, na altura, por um inglês - o marechal Beresford - e respectiva corte de oficiais, era precisamente 
à pedagogia britânica que as escolas regimentais iam beber, não só seu método - criado e desenvolvido por britânicos - mas também o perfil do professor, que moralmente influenciaria decisivamente os alunos: um homem organizado, dedicado, pontual, urbano, polido, franco, jamais exaltado, sem qualquer vestígio de rudeza ou grosseria. Enfim, o gentleman de Jonh Locke, por certo muito mais o cavalheiro britânico do que o sargento ou soldado do exército luso dos primórdios do século XIX.

Mas se o paradigma do professor era o de um lord britânico, bem mais nacional, porque arreigado aos valores tradicionais portugueses, era o fim que se desejava alcançar com esta alfabetização de militares ao querer que ela servisse para os levar a serem gente honrada, patriota, ciosa do seu Rei e amiga de Deus, isto é, homens de bem, bons vassalos e bons cristãos, isto sim, algo bem vincado na alma portuguesa.

\section{Referências bibliográficas}

MELO, João Crisóstomo do Couto (1821). Relatório do progresso das Escolas Militares de Primeiras Letras, de 15 de Outubro de 1821. In: CULTURA, Ministério da Educação e (1988). Colecção da Legislação Portuguesa: recolha efectuada para a área da educação (1808-1820) Lisboa: MEC, pp. IX-X.

(1822). Exposição do Novo Método d'Insino Mútuo seguido nas Escolas Militares de Primeiras Letras em Portugal, de 9 de Janeiro de 1822. In: IBIDEM, pp. V-VII.

.- PORTUGAL. Alvará de 15 de Dezembro de 1809. Estabelece as condições e idades de recrutamento para o exército. Publicado na Imprensa Régia em 1809.

.- PORTUGAL. Instruções de 17 de Junho de 1810. Interpretam o Alvará de 15 de Dezembro de 1809 e fixam a idade de recrutamento para o exército entre os 18 e os 40 anos de idade. Publicadas na Imprensa Régia em 1810.

.- PORTUGAL. Portaria de 28 de Setembro de 1813. Fixa a idade de recrutamento para o exército entre os 18 e os 30 anos de idade. Publicada na Imprensa Régia em 1813. 
.- PORTUGAL. Portaria de 10 de Outubro de 1815. Cria as Escolas de Primeiras Letras nos corpos de linha do exército e a Escola Geral para formação dos professores. Publicada na Imprensa Régia em 1815.

.- PORTUGAL. Alvará de 21 de Fevereiro de 1816. Regulamenta a organização do exército. Publicado na Imprensa Régia em 1816a.

.- PORTUGAL. Instruções de 29 de Outubro de 1816. Dão orientações aos professores das Escolas de Primeiras Letras dos corpos de linha do exército. Publicado na Imprensa Régia. 1816b.

RUAS, Henrique Barrilaro (1978). Educação de adultos em Portugal, no passado e no presente. In: GUSMÃO, Maria José; MARQUES, António J. G. (coord. de). Educação de Adultos. Braga: Universidade do Minho, pp.269300 .

\begin{abstract}
ANEXO $^{6}$
Exposição do novo método de ensino mútuo seguido nas escolas militares de primeiras letras em Portugal

$1^{\circ} \mathrm{O}$ mestre de uma escola de primeiras letras, regulada pelo ensino mútuo seguido na Escola Geral de Belém, logo que tomar conta dos seus discípulos examina o estado de instrução de cada um, tanto em ler, como em escrever, contar, doutrina cristã, etimologia, sintaxe e ortografia.
\end{abstract}

$2^{\circ} \mathrm{O}$ resultado dos exames feitos na forma prevista é lançado pelo mestre da escola num livro competente, declarando o nome do mestre com quem tiver aprendido o discípulo examinado. Nestes exames não há reprovação, porque servem unicamente para em todo o tempo se poder ajuizar do progresso dos discípulos e da bondade tanto do novo método como dos mestres.

$3^{\circ}$ Examinados todos os discípulos sobre o estado dos seus conhecimentos, o mestre os divide em secções de quatro cada uma, e começa por lhes ensinar o

\footnotetext{
${ }^{6}$ Transcrição do manuscrito de 9 de Janeiro de 1822 com as instruções sobre a aplicação do método de ensino mútuo nas escolas militares de primeiras letras, da autoria do Capitão de Engenharia João Crisóstomo de Couto e Melo ( apud Ministério da Educação e Cultura. Colecção da Legislação Portuguesa: recolha efectuada para a área da educação (1808-1820). Vol. IX. Lisboa: MEC, 1988. pp. V-VII).
} 
alfabeto (nomeando as consoantes conformemente ao emprego que cada uma tem no concurso para a formação das palavras, isto é: b, c (que), d, f, g, (gue), j (ge), l, m, n, p, qu, r, s, t, v, x, z, ç, ch (x), lh, nh) e, prontos que estejam alguns discípulos, o mestre os nomeia instrutores de outras tantas secções.

$4^{\text {o }}$ Instruídos pelo mestre todos os discípulos da sua secção, forma outra dos quatro instrutores que primeiro se habilitaram no alfabeto e lhes ensina o silabário (começando pelos sons primitivos simples, e passando depois aos primitivos combinados, assim orais como nasais; dando às consoantes das sílabas ra, re , ri, ro, ru, rá, ré, rí, ró, rú, e sa, se, si, so, su, sá, sé, sí , só, sú, as duas pronunciações distintas de quando estão em princípio ou meio de vocábulo, isto é, forte no primeiro caso e fraco no segundo, e começando por juntar as consoantes com as vogais de cada lição, e ler depois todas as sílabas da mesma lição, v.g.: b a, ba, b e, be, b i, bi, b o, bo, b u, bu, e logo ba, be, bi, bo, bu). Tanto que desta secção se habilita algum discípulo, o mestre o nomeia instrutor de outra secção de silabário e pratica assim com todos os discípulos da sua secção; de maneira que instruídos todas as quatro vem por fim a ter cinco secções de silabário com a que de novo forma assim (?).

$5^{\circ}$ Tanto que o mestre conhece que tem instrutores para as secções de silabário, forma uma secção para instrui-la no vocabulário, começando também por juntar as sílabas e ler depois os vocábulos da mesma lição, v.g. : an, dar andar; a, zar - azar; etc. E depois andar, azar, etc, e, apenas algum discípulo se apronta nesta espécie de leitura, o nomeia instrutor de vocabulário, e procede do mesmo modo até que a sua secção se converta toda em instrutores desta classe.

$6^{\circ}$ Chegando o mestre a não ter discípulos a quem ler e ensinar o vocabulário por ter já os instrutores precisos para as secções desta classe, forma uma secção para instrui-la na leitura corrente de frases e períodos, segundo a ortografia da pronunciação. 
$7^{\circ} \mathrm{O}$ mestre, procedendo na nomeação de instrutores de frases e períodos como a respeito dos instrutores de vocabulário, forma uma secção para instrui-la na leitura corrente de frases e períodos segundo a ortografia usual, e, desfeita que seja a sua secção por terem passado os discípulos dela a instrutores desta classe, forma a secção de leitura corrente em vida cristã.

$8^{\circ}$ Prontos alguns discípulos da última secção do mestre em leitura corrente, os nomeia instrutores desta mesma classe, e, finda a secção, forma outra para instruir os discípulos dela em leitura pelo resumo do catecismo romano, [finda] a qual, depois de devolvida em instrutores desta mesma classe, forma de novo outra de etimologia e assim mesmo procede na classe de sintaxe e ortografia, vindo, por último, a ter desta sorte distribuído o ensino das matérias compreendido na gramática portuguesa nas suas dez classes, a saber: $1^{\text {a }}$ alfabeto, $2^{\mathrm{a}}$ silabário, $3^{\mathrm{a}}$ vocabulário, $4^{\mathrm{a}}$ frases e períodos pela ortografia usual, $5^{\mathrm{a}}$ leitura corrente em vida cristã, $6^{\mathrm{a}}$ leitura corrente em catecismo romano, $7^{\mathrm{a}}$ etimologia, $8^{\mathrm{a}}$ sintaxe, e $10^{\mathrm{a}}$ ortografia.

$9^{\circ}$ Aos discípulos da $7^{\text {a }}$ classe dão-se temas de escrita dos mais bem escritos para eles os lerem na hora da leitura, tendo-se como distinção honorífica o darse para leitura uma escrita feita por discípulos da mesma escola.

$10^{\circ}$ A elevação dos discípulos de uma classe à imediata pratica-se inalteravelmente na última vez de aula de cada semana, tendo o mestre à sua vista as escalas diárias, para delas deduzir com justiça o conhecimento dos discípulos que, em virtude da sua aplicação, se fizeram dignos de acesso.

$11^{\circ}$ Distribuídos que estejam todos os discípulos de uma escola da maneira prescrita, começa o mestre a instruir na segunda hora de aula uma secção de seis discípulos na escritura das letras maiúsculas sobre areia (espalhando-a em tabuleiros ou sobre mesas que tenham uma espécie de caixilho para impedir que a arei caia fora), mostrando aos discípulos donde as mesmas letras se devem começar a escrever e a forma que se deve dar à mão direita, deixando 
apenas o dedo mostrador estendido para servir de pena, e pondo-lhes de frente os exemplares das letras que hão-de escrever seguindo-os inteiramente.

$12^{\circ}$ Instruídos os discípulos todos na escritura das letras maiúsculas (em cuja instrução lhes deve falar delas, pelos seus nomes), forma o mestre outra secção para instrui-la na escritura das letras minúsculas, guardando inalteravelmente a figura, proporção e inclinação que mostram os exemplares gravados que se acham fornecidos a todas as escolas militares.

$13^{\text {a }}$ Comunicada a precedente instrução pelos respectivos instrutores a todos os discípulos restantes, o mestre forma uma secção de seis discípulos dos mais adiantados desta segunda classe para os instruir em escreverem sobre pedra ardósia os elementos das letras e vai progressivamente distribuindo este ensino, [tão] bem como [o] praticou na $1^{\mathrm{a}}$ e $2^{\mathrm{a}}$ classe de escrita e em todas as de gramática. A progressão, pois, do ensino de escritura, abrange dez classes, a saber: $1^{\mathrm{a}}$ letras maiúsculas, $2^{\mathrm{a}}$ letras minúsculas, $3^{\mathrm{a}}$ elementos das letras até à sétima lição, $4^{\mathrm{a}}$ elementos das letras até à décima quinta lição, $5^{\mathrm{a}}$ alfabetos minúsculos, $6^{\mathrm{a}}$ algarismos, $7^{\mathrm{a}}$ alfabetos maiúsculos, $8^{\mathrm{a}}$ escrita corrente por tratado, $9^{\mathrm{a}}$ escrita corrente por livro e, $10^{\mathrm{a}}$, escrita corrente ditando-se (em pedra e papel).

$14^{\circ} \mathrm{Na}$ escrita de alfabetos minúsculos sobre areia deve o mestre ensinar a figurar os algarismos falando deles pelos seus nomes; e esta mesma prática deverá seguir na escrita em pedra e papel, sem discrepância dos modelos gravados que para esse fim se acham nas escolas particulares do exército.

$15^{\circ}$ Distribuídos assim os discípulos na segunda hora de aula, principia o mestre na terceira hora a instruir uma secção de quatro em contar pelo sistema prático; e depois que tem algum discípulo habilitado na conta $\mathrm{n}^{\circ} 1$ o nomeia instrutor de uma segunda secção desta conta, e procedendo assim até à conta $\mathrm{n}^{\circ}$ 8, para o que o mestre deve ter habilitado os respectivos instrutores, forma uma secção de novo para lhe ensinar a somar números inteiros e decimais e, prontos 
que estejam os discípulos dela, os distribui em instrutores de secções desta classe, passando logo a instruir novas secções na diminuição de números inteiros e decimais e assim do mesmo modo até à divisão destes mesmos números, empregando sempre o uso das tábuas competentes.

$16^{\circ}$ Formada toda a escola em seis classes de instrução de contar pelo sistema prático, a saber, $1^{\mathrm{a}}$ leitura e escritura de números inteiros, $2^{\mathrm{a}}$ leitura e escritura de números decimais, $3^{\mathrm{a}}$ adição, $4^{\mathrm{a}}$ subtracção, $5^{\mathrm{a}}$ multiplicação, $6^{\mathrm{a}}$ divisão, o mestre forma dos discípulos habilitados na $8^{a}$ classe (de gramática) uma secção que poderá constar de seis até oito discípulos e começa por instrui-la nos princípios gerais e operações fundamentais de aritmética. Depois formará mais três secções, sendo a $8^{\mathrm{a}}$ das operações sobre os números quebrados e complexos, a $9^{a}$ sobre as razões, proporções e regra de três termos, e a $10^{\mathrm{a}}$ nas operações fundamentais da linguagem do cálculo.

$17^{\mathrm{a}}$ Concluir se deve, do que fica expendido, que só depois da distribuição dos discípulos da aula em classes de contar praticamente é que se tem três horas de ensino em cada yez de aula, sendo a $1^{\circ}$ gramática, a $2^{\mathrm{a}}$ caligrafia, e a $3^{\mathrm{a}}$ de aritmética, e que, no andamento da formação das secções de ensino, tanto em gramática, como em caligrafia e aritmética, se observam regular e uniformemente os mesmos princípios de habilitação de instrutores para, a final, se ver o mestre unicamente encarregado de vigiar a marcha das diferentes secções em cada diversa hora de ensino. Tal é uma das vantagens que apresenta o novo método, ensaiado e comprovado na Escola Geral de Belém, para instrução normal dos professores das escolas particulares dos corpos do exército, no qual se acham reunidos os três pontos característicos do novo método de ensino mútuo: classificação, reciprocidade e distinção.

$18^{\circ} \mathrm{O}$ ensino da doutrina cristã fornece duas classes somente: o mestre se encarrega de uma secção de 15 até 20 discípulos e lhes ensina por forma de 
diálogo e, tanto que tem alguns discípulos habilitados, os nomeia instrutores de secções de seis desta mesma classe.

$19^{\circ}$ Distribuídos todos os discípulos em secções de doutrina oral, o mestre forma secções de doutrina lida e explicada de cor, nomeando para instrutores delas os discípulos habilitados na $1^{\mathrm{a}}$ classe e que já tiverem passado à $6^{\mathrm{a}}$ classe de gramática. Destes mesmos instrutores deve o mestre formar uma secção para instrui-los na ajuda à missa, acompanhando-os nas primeiras vezes que forem praticar esta instrução.

$20^{\circ}$ Está recomendado ao mestre da aula que os castigos determinados pelas instruções que servem de regulamento às escolas somente se devem aplicar no fim da última hora de aula e sempre com a circunspecção recomendada pelo Director das escolas. [Motivo] por que o mestre deve empregar sempre, com preferência, a privação de prémio como castigo ordinário.

$21^{\circ}$ Os discípulos que merecem o primeiro lugar nas relações [do modelo] B têm para sua distinção o seu assento ao lado do mestre num banco, em cuja frente está escrito com caracteres brancos e muito distintos Mérito e, se há discípulo que mereça em todas as quatro relações [do modelo] B o primeiro lugar, ele só tem assento no primeiro banco à direita do seu mestre, ficando os mais bancos voltados.

$22^{\circ}$ Os discípulos que pretenderem fazer seus exames nas diferentes classes de instrução, pode o mestre admiti-los em três dias para isso mesmo destinados, nos primeiros dias de aula dos meses de Junho e Dezembro de cada ano. O mestre franqueia a assistência aos ditos exames a toda a pessoa que quer concorrer a eles e manda ao Director das Escolas uma relação nominal dos discípulos examinados, declarando o resultado que tiveram, em que matéria versaram os exames e quanto tempo tinham de estudo, para que o mesmo Director possa conhecer não só do progresso da escola, como igualmente dos talentos dos discípulos aprovados. 
$23^{\circ}$ No princípio de cada mês, recebe o Director das Escolas uma escala do modelo E do progresso que todas elas fizeram no mês antecedente e, destas mesmas escalas, extrai outras que envia a S. ${ }^{a}$ Ex. ${ }^{a}$ o Ministro e Secretário de Estado dos Negócios da Guerra.

$24^{\circ}$ No princípio de cada ano, todas as escolas remetem igualmente ao seu Director um mapa do progresso e movimentos que ocorreram no precedente ano, conforme o modelo $\mathrm{F}$, do qual [se] deduz o conhecimento dos diversos artigos de que o mesmo Director é obrigado a dar conta em sessão pública presidida por S. ${ }^{a}$ Ex. ${ }^{a}$ o dito Ministro e Secretário de Estado.

$25^{\circ}$ A correspondência das escolas é feita entre o Director delas e os ajudantes dos corpos [do exército] que, nas mesmas escolas, servem como de seus directores particulares, devendo comunicar aos chefes dos mesmos corpos [do exército] tudo [aquilo] que for objecto de sua correspondência com o Director Geral.

$26^{\circ} \mathrm{O}$ provimento dos empregos de professores das escolas é feito por proposta do Director das escolas a S. ${ }^{a}$ Ex. $^{\text {a }}$ o Ministro e Secretário de Estado dos Negócios da Guerra, de entre os candidatos habilitados na Escola Geral, em cujo tempo de habilitação, sendo militares, vencem, além de soldo e pão, 60 reis diários para rancho e, sendo paisanos, o soldo de cabo de esquadra de infantaria e os mesmos 60 réis para o rancho.

$27^{\circ} \mathrm{O}$ mestre de uma escola militar tem a graduação, soldo e mais vencimentos do primeiro sargento da arma a que pertence a escola e de mais 2000 réis diários a título de gratificação de trabalho. O seu ajudante vence como segundo sargento agregado e 100 réis por dia de gratificação de trabalho, mas, na ausência do mestre, vence os 200 réis atribuídos ao trabalho deste emprego. 
$28^{\circ}$ A despesa com o expediente de qualquer escola está regulada a $8 \$ 00$ por ano e recebem-se cada mês 665 réis que se entregam ao mestre dela para comprar os artigos precisos para a sua correspondência oficial e para a mesma escola.

Carnide. 9 de Janeiro de 1822.

João Crisóstomo de Couto e Melo

Dir. das Esc.

\section{Autor:}

José Carlos de Oliveira Casulo - Filiação institucional: Professor da Universidade do Minho (Instituto de Educação/Centro de Investigação em Educação), em Braga, Portugal

Contato: jcasulo@iep.uminho.pt

\section{Como citar este artigo:}

CASULO, José Carlos de Oliveira. Um projecto novecentista para alfabetização do exército português. Revista ACOALFAplp: Acolhendo a Alfabetização nos Países de Língua portuguesa, São Paulo, ano 4, n. 7, 2009. Disponível em: <http://www.acoalfaplp.net>. Publicado em: setembro 2009.

Recebido em maio de 2009./ $\quad$ Aprovado em junho de 2009. 